\title{
Would-Be Teachers' Competence in Applying ICT: Exposition and Preconditions for Development
}

\author{
Palmira PEČIULIAUSKIENĖ, Marija BARKAUSKAITE் \\ Department of Education Science, Pedagogical University \\ Studentu 39, 08106 Vilnius, Lithuania \\ e-mail: palmira.p@post.skynet.lt,edukologija@vpu.lt
}

Received: April 2007

\begin{abstract}
Changes in educational technologies modify the role of the teacher and require new competencies. Scientific literature describes competence in using ICT as the wholeness of two structural components - basic and educational ICT competence. The conception has been considered conducting research on would-be teachers' competence in applying ICT. The article deals with the exposition of would-be teachers' competence in applying ICT in the process of teaching practice and focuses on the impact of studying informatics in forms 11 and 12 on the development of the latter competence. Research disclosed that would-be teachers had fully mastered ordinary abilities demonstrating basic and educational competencies in ICT. The development of would-be teachers' competence has been accepted as a permanent process starting yet before the studies at university within the process of learning informatics in forms 11 and 12.
\end{abstract}

Key words: competence in applying ICT (competence in ICT), basic ICT competence, educational ICT competence.

\section{Introduction}

Changes in educational technologies are rotational phenomena. Variation in technological resources leads to discovering new teaching aids. In the 17th century, verbally and exemplary based educational technologies were supplemented with teaching technologies supported by the course book. In the second half of the 20th century, educational practice started using information and communication technologies. In the 21 st century, the education systems are increasingly obliged to use new information and communication technologies (ICT) providing knowledge for the learners/students and exercising abilities and skills.

Teaching based on the grounds of information and communication technologies has a positive evaluation. It has been established that new ICT effectively helps with achieving educational goals and develops learners' information and communication abilities necessary for professional activity in the future (Papert, 1997; Cuban, 2001; Fuchs and Woessmann, 2004). Applying ICT allows using techniques of programmed teaching (Ozmon and Carver, 1996) and develops preconditions for producing new learning environments suitable for constructive studying (Jonassen, 1996; Coughlin, 1999; Schacter, 1999; Dexter et al., 2000; Knierzinger et al., 2002). Some researchers and practitioners are having 
a discussion whether a computer is efficient enough to completely change the teaching process (Becker and Anderson, 1998; Becker and Ravitz, 2001; Fulton, 1997). Obviously, ICT have the advantage in the learning process only when present and would-be teachers manage to effectively use these technologies in educational practice. The teachers successfully applying ICT these days will achieve good results working with future technologies (Hattler, 1999; Wong and Li, 2006).

Changes in educational technologies make the teacher's role different and require new competencies. The teacher's competence in information communication technologies (ICT competence) consists of knowledge, abilities, approaches, values and other personal qualities determining successful ICT use in educational practice (Ashworth and Saxton, 1991; Cuban, 2001). Competence in ICT is formed within studies at higher school, independent learning, collaboration and other activities. The preconditions for developing competence in ICT can be subdivided into two categories - formal (studying at higher/comprehensive school) and informal (studying through collaboration, independent studies, the learner's motivation, relationship between a learner and a user). The majority of the universities train would-be teachers to use ICT in educational practice. However, these educational establishments poorly concentrate on how the teachers apply ICT in educational practice and what competence in ICT they have. Therefore, feedback ensured by the students' educational practice is unfavourably received.

Teaching practice is the period that discloses competence in ICT and its quality. Following the Lithuanian model of teacher training the students are given some time for competence reflexion and correction when practice is over. The above mentioned preconditions settled the problem of research - What is the students-would-be teachers' competence in ICT and how its exposition depends on formal studies?

The goal of the article is to evaluate the exposition of the students-would-be teachers' competence in ICT in teaching practice concerning preconditions developed in formal studies.

The following tasks make the goal of research more specific:

1. What is the level of competence in ICT of the students carrying on teaching practice?

2. How does basic ICT competence of would-be teachers relate to learning informatics in comprehensive school?

3. How does educational ICT competence of would-be teachers relate to learning informatics in comprehensive school?

\section{Background}

In order to evaluate the exposition of the students-would-be teachers' competence in ICT and preconditions for its development, the structure and content of competence in ICT must be clearly defined. A part of researchers agree that successful use of ICT in educational practice depends on didactical competence, ICT literacy and ICT pedagogical competence (Andersen and Brink, 2002), the others point to some more components in- 
cluding pedagogy, social and ethical issues, knowledge of technology, professional improvement and organization of teaching (Coughlin, 1999; Knierzinger et al., 2002; Resta et al., 2002). The researchers from Finland emphasize that would-be teachers must study technical and pedagogical subjects that create preconditions for developing the most important components of competence in ICT including literacy and didactical preparation (Rautopuro et al., 2006). Therefore, competence in ICT embraces two structural components - ICT literacy and ICT competence in didactics. Some authors describe ICT literacy as ordinary skills in ICT being developed and improved for life (Witfelt, 2000; Li et al., 2006). Hence, ICT literacy can be treated as a dynamic rather than static component that requires renovation and expansion in order to reflect changes in the context.

The didactic component of competence in ICT mainly implies the ability to adapt ICT in educational practice. The integrity of ICT literacy and the didactic component are ensured by the needs of a teacher. The flow of ICT technologies to educational practice shows how the teacher's needs may vary from training in using ICT to the need for how to learn ICT integration into educational practice (Troter and Ellison, 2001). In a number of countries, technical and didactical sides of competence in ICT are considered in teacher training. However, more frequently the use of technologies rather than integration of ICT into educational practice are emphasized in the teaching process (Rautopuro et al., 2006).

A few researchers (Shapiro and Hughes, 1996; Markauskaite, 1999) accentuate two levels of competence in ICT - basic and extended abilities. The basic abilities are the core of ICT use consisting of computer literacy, knowledge, information and skills to operate the acquired data, knowledge of law and appropriate moral attitudes. The extended abilities fulfil the basic ones and cover knowledge and skills necessary to rationally apply information technology to different fields of science, culture and social life. A comparison of the latter researchers' approach to competence in ICT with the above introduced standpoints obviously reveals some commonalities. The component of ICT literacy conforms to the level of the basic abilities while the didactical component agrees with the extended abilities.

Competence in ICT is dynamic and dependable on the alterations in educational technologies and the factors of the teacher's work environment (Anderson et al., 2002; Li et al., 2006)). Four stages of integrating ICT technologies can be marked: introduction, application, inclusion and transformation (Anderson, 2002, Jucevičienè and Brazdeikis, 2003; Dagienè, 2004). Concerning the four stages of ICT integration, the competence structure of the teachers' ability to use ICT falls into four levels: behaviouristic, enclosed, integrated and holistic. Apart from the spread of competence in ICT into four levels, the components including basic and integral educational ICT competence remain stable (Coughlin, 1999; Andresen and Brink, 2002; Jucevičienė and Brazdeikis, 2003).

The structure of competence in using the two components (basic ICT literacy and integral educational ICT) is disclosed in the standards of using ICT by the teachers: ISTE (International Society for Technology in Education, 2000) and Teacher Computer Literacy Standard (2001).

The conclusion of foreign researchers' approaches (Ashworth, and Saxton, 1991; Shapiro and Hughes, 1996; Anderson et al., 2002; Andresen, 2002) towards ICT content and structure drawn by Lithuanian investigators (Urbonaitè, 1999; Jucevičienè and 
Brazdeikis, 2003) suggest defining competence in ICT as the wholeness of basic and integral educational ICT competence. Basic ICT competence comprises the ability to use and manipulate ICT, be informationally literate and knowledgeable about how to apply social, ethical and legal issues concerning ICT. Integral educational ICT (educational ICT) competence covers the ability to apply ICT in educational practice and to develop learners' computer literacy including the ability to plan, operate and analyse the processes of applying ICT. The research discussed in the article is based on the conception of the content and structure of competence in ICT.

The foreign researchers have investigated would-be teachers' competence in ICT within teaching practice from different angles: collaboration, learning experience, trust etc. When examining experience of the would-be teachers-mathematicians Robert Powers et al. (2005) points to high level of the students' knowledge and ability to use technologies as a teaching tool. Successful collaboration allows the teachers-mentors to broaden experience working with the students would-be teachers within teaching practice. Eunjoo Oh and Russell French (2002) states that successful ICT application depends on preparation of both the present and would-be teachers. Would-be teachers must possess practical skills at using computer technologies in the processes of teaching and learning. When dealing with information technologies, knowledge as well as teachers' reliance on possibility of effective use of the obtained information must be taken into consideration. An examination of the PISA (Programme for International Student Assessment) research in Finland performed by Rautopuro et al. (2006) shows that positive results can be directly related to applying ICT in educational practice. The researchers presume that in order to make would-be teachers engaged and ready for using ICT at work more attention should be devoted to their learning experience. The results presented by the Finish researchers indicate that such qualities as 'motivation and precision', 'relationship between the learner and the user' and 'supervision for the learner and independent learning' should encourage would-be teachers to apply ICT at work.

The review of literature sources shows that competence in ICT and development preconditions have been examined from different angles. However, we focused on another precondition for developing competence in ICT which is learning informatics in comprehensive school.

\section{Research Methodology}

Research methodology is based on the concept of meaningful learning. Jonassen (1999) maintains that meaningful learning can be related to constructivism, reflectivity, collaboration, activity, intentionality and contextuality. The methodological approach of research described in this article refers to constructivism and reflectivity. Considering this position, the learner should extend a new knowledge on the basis of already available information. In this case, reflexion is extremely important. To conform to the new situations of studying, a learning environment should help the students with self-evaluation of studies and previously acquired knowledge (Jonassen, 1999; Jonassen et al., 1999). 


\section{Sample and Procedure}

The article looks at students' competence in ICT on the basis of students' reflexion. The article discusses the survey data on would-be teachers' competencies in ICT. The above introduced extensive research was conducted in Vilnius Pedagogical University and was targeted at evaluation of pedagogical competencies gained by the students within teaching practice. The students' competencies revealed along practice were evaluated by the learners taught, the students themselves and the teachers-mentors who were monitoring the process of teaching practice.

The model of the survey was chosen and the sample was provided applying the methods used in IEA international research (International Association of the Educational Achievement). To carry on research, a random students' sample was used. The principle of sampling is a random cluster sample based on randomly chosen students' groups when a sample comprises all the students of a particular group rather than single respondents. The students from different departments participated in the survey, i.e., the respondents studying exact (mathematics, informatics), natural (physics, chemistry and biology), social, technological sciences and the humanities were surveyed one month after teaching practice had been over. 900 bachelor's degree students in total were questioned. Hence, the research sample is reliable and presentable.

To evaluate competence in ICT of the students who were carrying on teaching practice quantitative research was applied. The questionnaire was accepted as the instrument of the survey. In order to establish competence in ICT, two sections of integrated questions were introduced. Section 1 included questions about basic ICT competence (computer literacy). The answers had to be provided along with self-evaluation of basic ICT competences displayed within teaching practice. These competencies embrace a wide spectrum of technical ICT activity: from worksheets in the classroom to educational software, personal websites on the Internet and organization of remote learning. Obviously, these activities require different level of basic ICT competences. The questions included in the questionnaire considered these issues, and therefore the students had to evaluate different abilities making basic ICT competence (Table 1).

Section 2 contained questions discussing educational ICT competence based on educational experience at different level and covered the ability to apply visual static educational material in the classroom, to employ active methods of teaching, to create problematic situations in the classroom using ICT etc. (Table 4).

To evaluate competence in ICT, the rank scale of measurement and three evaluation ranks 'succeeded', 'partly succeeded' and 'failed' were introduced. Technical preconditions were considered to be required elements of showing competence in ICT. Therefore, along the three evaluation ranks describing competence, an extra answer 'missed' was added. The latter version was chosen by the respondents who had no technical possibilities of applying ICT in teaching practice. Moreover, this answer was popular among those who though having technical preconditions did not employ them.

Research revealed two formal preconditions for developing competence in ICT: learning informatics in secondary school and studies of developing competence in ICT in 
higher school. The learners of Lithuanian upper secondary school (Forms 11 and 12) can choose between an advanced (higher level) and general (lower level) level of the course on informatics. The older part-time students who graduated from secondary school some time ago might not be introduced a course on informatics. 281 students learnt informatics at advanced and 455 - at general level whereas 164 students did not study informatics in secondary school. Under the available regulations of teacher training, teaching practice is submitted in the fourth (last) year of bachelor studies. Thus, a three year period goes past since the last studies of informatics in comprehensive school.

The second precondition for developing competence in ICT covers studies in higher school. The certain modules of developing competence in ICT are included in the curricula of studies at all departments of Vilnius Pedagogical University. The modules are under the obligation law About Teacher Computer Literacy Standard passed by the Minister of Education and Science of the Republic of Lithuania and must take from 2 to 4 credits. A particular amount of hours is devoted to perform individual tasks.

\section{Research Framework and Data Analysis}

To process research data, descriptive statistics was applied. In order to evaluate statistical significance of different positions, the percentage of the answers was calculated. The $\chi^{2}$ (chi square) test was used to examine homogeneity of population. The chosen level of significance $(\alpha)$ was 0.05 . If the calculated $p$-value 0.05 , the difference is statistically significant. Otherwise, it is statistically insignificant.

To statistically process data of research, the statistical packet SPSS 13 was applied.

\section{Measures}

\subsection{Basic ICT Competence of Would-Be Teachers and Preconditions for Development}

The fundamentals of basic ICT competence include the abilities of using ICT and information abilities. They are supplemented with knowledge of social and ethical laws, the rules of law and the ability to follow them in ICT educational practice. To prepare the questionnaire, the abilities to use ICT were specified considering their level of difficulty. The respondents had to show more or less complex abilities to use ICT in practice: working with text for schooling purposes using ICT, producing visual (static, dynamic, audio equipped etc.) educational material, designing educational software etc. (Table 1).

Research data (Table 1) indicates that within teaching practice would-be teachers succeeded in finding relevant texts, partly succeeded - in producing static visual material, using electronic databases for educational purposes and using the Internet for effective communication, i.e., they managed to implement the activities requiring ordinary abilities which are the fundamentals of basic ICT competence.

A number of the respondents did not produce visual, dynamic or audio-equipped educational material (63.1\%), educational software (95.8\%), use the Intranet (90.2\%), deal 
Table 1

Basic ICT competence of would-be teachers: the percentage of self-evaluation

\begin{tabular}{|c|c|c|c|c|}
\hline \multirow{2}{*}{ Abilities demonstrating basic ICT competence } & \multicolumn{3}{|c|}{ Evaluation rank } & \multirow{2}{*}{ Missed } \\
\hline & Succeeded & Partly Succeeded & Failed & \\
\hline Working with text for schooling purposes using ICT & 89.2 & 1.6 & 4.0 & 5.4 \\
\hline $\begin{array}{l}\text { Producing visual static educational material } \\
\text { using ICT }\end{array}$ & 28.1 & 36.5 & 15.5 & 19.9 \\
\hline $\begin{array}{l}\text { Producing visual dynamic (animated) } \\
\text { educational material using ICT }\end{array}$ & 8.3 & 14.9 & 13.7 & 63.1 \\
\hline $\begin{array}{l}\text { Producing visual dynamic audio-equipped } \\
\text { educational material using ICT }\end{array}$ & 9.8 & 11.5 & 15.2 & 63.5 \\
\hline Designing educational software & 1.5 & 0.9 & 1.8 & 95.8 \\
\hline $\begin{array}{l}\text { Using the Internet for the purposes of } \\
\text { educational material }\end{array}$ & 8.3 & 14.9 & 13.7 & 63.1 \\
\hline Using the Internet for effective communication & 5.1 & 39.4 & 17.6 & 37.9 \\
\hline Using electronic databases for educational purposes & 21.3 & 45.0 & 5.0 & 28.5 \\
\hline Creating personal websites on the Internet & 1.3 & 0.9 & 0.8 & 97.0 \\
\hline Using the Intranet & 3.8 & 5.8 & 0.2 & 90.2 \\
\hline Remote learning possibilities & 0.2 & 0.2 & 0.3 & 99.3 \\
\hline
\end{tabular}

with remote learning $(99.3 \%)$ or create personal websites $(97.0 \%)$. The evaluation of the latter result points to two crucial factors - lack of competence in ICT and poor technical basis. Stimulating the process of remote teaching and using the Intranet are clearly limited due to technical preconditions. However, the possibilities of technical preconditions that could help with producing visual educational material, developing educational material, creating personal websites on the Internet were offered all respondents having an opportunity to use computers. Therefore, supposedly the implementation of these activities was determined by insufficient basic ICT competence.

Relation between basic ICT competence and the format of learning informatics in forms 11 and 12 was examined. 4 of 11 cases indicate that statistically significant deviation $(p<0.05)$ between basic ICT competence of the respondents who learnt informatics in school at advanced level and those who studied the subject at general level or did not study at all was established (Table 2). In all other cases of the survey, concerning the format of learning informatics in forms 11 and 12, statistical deviation between basic ICT competence was found insignificant $(p>0.05)$. The previous data should be considered along the interpretation of the results obtained (Table 1). No statistically significant deviation was noticed because nearly all surveyed respondents $(90.2 \%-99.3 \%)$ did not implement such activities as designing educational software, creation of personal websites on the Internet, the use of the Intranet and possibility of remote teaching.

Some abilities to operate basic ICT competence (working with text for schooling purposes using ICT, the use of the Internet for the purposes of efficient correspondence, the use of electronic databases) do not relate to the format of learning informatics in forms 11 and $12(p>0.05)$. Thus, the respondents who studied informatics in forms 11 and 12 
Table 2

Basic ICT competence of would-be teachers and the format of learning informatics: statistical significance of deviation

\begin{tabular}{lrcc}
\hline Abilities demonstrating basic ICT competence & $\chi^{2}$ & df & $p$ \\
\hline Working with text for schooling purposes using ICT & 15.11 & 6 & 0.112 \\
Producing visual static educational material using ICT & 19.53 & 6 & $\mathbf{0 . 0 0 2}$ \\
Producing visual dynamic (animated) educational material using ICT & 20.13 & 6 & $\mathbf{0 . 0 0 3}$ \\
Producing visual dynamic audio-equipped educational material using ICT & 23.33 & 6 & $\mathbf{0 . 0 0 0}$ \\
Designing educational software & 6.22 & 6 & 0.084 \\
Using the Internet for the purposes of educational material & 18.41 & 6 & $\mathbf{0 . 0 1 8}$ \\
Using the Internet for effective communication & 11.21 & 6 & 0.071 \\
Using electronic databases for educational purposes & 10.630 & 6 & 0.224 \\
Creating personal websites on the Internet & 2.078 & 6 & 0.721 \\
Using the Intranet & 8.440 & 6 & 0.392 \\
Remote learning possibilities & 12.236 & 6 & 0.141 \\
\hline
\end{tabular}

at advanced level and those who did not or learnt the subject at general level equally succeeded in working with text for schooling purposes using ICT and using the Internet for the purposes of effective correspondence and creation of electronic databases. The above introduced abilities demonstrating basic ICT competence are not complex, easy mastered and can be developed through professional activities as well as through communication and collaboration in daily life.

The evaluation of the following abilities, the constituents of basic ICT competence including produced visual static and dynamic (animation and audio-equipped) educational material using ICT, and the use of the Internet to find required information disclosed statistically significant deviation $(p<0.05)$. To interpret the motives of this statistically confirmed deviation, the data of research was grouped considering the format of learning informatics in forms 11 and 12 (Table 3). According to the figures, the respondents who studied informatics in forms 11 and 12 at advanced level better applied ICT to produce visual static, dynamic and dynamic audio-equipped teaching material.

Statistically significant deviation was established only when examining more complex abilities demonstrating basic ICT competence, i.e., the abilities requiring a broader knowledge of informatics (Table 2). Thus, it is supposed that learning informatics in forms 11 and 12 have an impact on developing the abilities that need a wider knowledge of informatics.

\subsection{Educational ICT Competence of Would-be Teachers}

Educational ICT competence can be defined as the ability to use ICT in educational practice and to develop learners' computer literacy and capability of planning, manipulating and analyzing the processes of ICT application. This research examines the abilities of using ICT in educational practice (Table 4). The abilities to plan, manipulate and analyze were not investigated. 
Table 3

Basic ICT competence of would-be teachers and the format of learning informatics

\begin{tabular}{|c|c|c|c|c|c|}
\hline \multirow{2}{*}{$\begin{array}{l}\text { Abilities demonstrating } \\
\text { basic ICT competence }\end{array}$} & \multirow{2}{*}{$\begin{array}{l}\text { Level of learning } \\
\text { informatics }\end{array}$} & \multicolumn{3}{|c|}{ Evaluation rank } & \multirow{2}{*}{ Missed } \\
\hline & & Succeeded & Partly Succeeded & Failed & \\
\hline \multirow{2}{*}{$\begin{array}{l}\text { Producing visual static } \\
\text { educational material using ICT }\end{array}$} & Advanced & 31.0 & 32.7 & 5.7 & 30.6 \\
\hline & General /not learned & 15.6 & 21.9 & 15.6 & 46.9 \\
\hline \multirow{2}{*}{$\begin{array}{l}\text { Producing visual dynamic } \\
\text { (animated) educational } \\
\text { material using ICT }\end{array}$} & Advanced & 21.0 & 22.4 & 9.6 & 47.0 \\
\hline & General /not learned & 3.1 & 14.1 & 12.5 & 70.3 \\
\hline \multirow{2}{*}{$\begin{array}{l}\text { Producing visual dynamic } \\
\text { audio-equipped educational } \\
\text { material using ICT }\end{array}$} & Advanced & 24.6 & 39.5 & 5.3 & 30.6 \\
\hline & General /not learned & 0.0 & 42.2 & 3.1 & 54.7 \\
\hline \multirow{2}{*}{$\begin{array}{l}\text { Using the Internet for the } \\
\text { purposes of educational } \\
\text { material }\end{array}$} & Advanced & 4.9 & 15.0 & 14.1 & 66.1 \\
\hline & General /not learned & 6.3 & 6.3 & 14.1 & 73.4 \\
\hline
\end{tabular}

Table 4

Educational ICT competence of would-be teachers: the percentage of self-evaluation

\begin{tabular}{|c|c|c|c|c|}
\hline $\begin{array}{l}\text { Abilities demonstrating } \\
\text { educational ICT competence }\end{array}$ & Succeeded & $\begin{array}{c}\text { Partly } \\
\text { succeeded }\end{array}$ & Failed & Missed \\
\hline $\begin{array}{l}\text { Presentation of visual educational material produced } \\
\text { by other authors using computer assistance }\end{array}$ & 22.5 & 42.1 & 10.6 & 24.8 \\
\hline $\begin{array}{l}\text { Presentation of visual educational material produced } \\
\text { by the students themselves using computer }\end{array}$ & 28.1 & 36.5 & 15.5 & 19.9 \\
\hline Using educational software & 29.5 & 7.1 & 8.6 & 54.8 \\
\hline Using the Internet in the classroom & 8.3 & 14.9 & 13.7 & 63.1 \\
\hline $\begin{array}{l}\text { Using enriched ICT learning environments in the } \\
\text { classroom (multimedia, hypertext) }\end{array}$ & 3.2 & 14.6 & 11.1 & 71.1 \\
\hline $\begin{array}{l}\text { Applying ICT in the classroom using traditional } \\
\text { methods of teaching }\end{array}$ & 14.1 & 18.2 & 11.0 & 56.7 \\
\hline $\begin{array}{l}\text { Applying ICT in the classroom using active methods } \\
\text { of teaching }\end{array}$ & 10.3 & 15.3 & 17.7 & 56.7 \\
\hline Applying ICT to evaluate students' achievements & 25.9 & 11.0 & 13.3 & 49.8 \\
\hline
\end{tabular}

The abilities demonstrating educational ICT competence were studied from three angles including application of teaching aids, teaching techniques and evaluation of learners' achievements. The abilities to apply teaching aids were specified considering the format of a teaching aid: presentation of visual educational material using ICT, the use of educational software, the Internet and enriched learning environments. The application of teaching methods was also clearly defined and embraced traditional (teacher-centred) and active (learner-centred) methods of teaching.

Research revealed that within teaching practice, the students managed to employ ICT 
in the classroom and made visual presentations using computer assistance, applied educational software, the Internet, used enriched learning environments. Moreover, when evaluating knowledge of the learners would-be teachers used ICT applying traditional and active methods of teaching. However, less than one third of the respondents succeeded in applying ICT in the classroom. More than a half of the surveyed participants missed an opportunity of using educational software (54.8\%), the Internet (63.1\%) and enriched learning environments $(71.1 \%)$ in the classroom. It should be stressed that a similar percentage (56.7) of the respondents did not use ICT when applying traditional (teacher-centred) and active (learner-centred) methods of teaching.

Educational ICT competence of the students is improved in pedagogical university going into the modules developing ICT competencies and being involved in teaching practice. Moreover, educational and basic ICT competences are coherent (Anderson $e t$ al., 2002). The format of learning informatics in forms 11 and 12 has the impact on developing extraordinary abilities demonstrating basic ICT competence. Considering the situation, an investigation into relation between educational ICT competence and the format of learning informatics in forms 11 and 12 was carried out (Table 5).

4 of 8 cases show that educational ICT competence has relation with the format of learning informatics in forms 11 and 12. Statistically significant deviation between positions of the respondents who learnt informatics in school at advanced level and those who did not learn the subject or studied it at general level was established. Statistically significant deviation was discovered evaluating the following abilities demonstrating educational ICT competence: presentation of visual educational material produced by the students using computer assistance, using enriched ICT learning environments in the classroom (multimedia, hypertext), applying ICT in the classroom using traditional and active methods of teaching. It should be underlined that statistically significant deviation was noticed evaluating abilities that demonstrate educational ICT competence and require extraordinary abilities demonstrating basic ICT competence.

Table 5

Educational ICT competence of would-be teachers and the format of learning informatics: statistical significance of deviation

\begin{tabular}{lccc}
\hline Abilities demonstrating educational ICT competence & $\chi^{2}$ & df & $p$ \\
\hline $\begin{array}{l}\text { Presentation of visual educational material produced by other authors using } \\
\text { computer assistance }\end{array}$ & 17.11 & 6 & 0.118 \\
$\begin{array}{l}\text { Presentation of visual educational material produced by the students themselves } \\
\text { using computer }\end{array}$ & 21.33 & 6 & $\mathbf{0 . 0 0 1}$ \\
Using educational software & 10.05 & 6 & 0.093 \\
Using the Internet in the classroom & 13.62 & 6 & 0.111 \\
Using enriched ICT learning environments in the classroom (multimedia, & 27.22 & 6 & $\mathbf{0 . 0 0 0}$ \\
hypertext) & & & $\mathbf{0 . 0 1 9}$ \\
Applying ICT in the classroom using traditional methods of teaching & 19.01 & 6 & $\mathbf{0 . 0 1 9}$ \\
Applying ICT in the classroom using active methods of teaching & 29.87 & 6 & $\mathbf{0 . 0 0 0}$ \\
Applying ICT to evaluate students' achievements & 11.29 & 6 & 0.081 \\
\hline
\end{tabular}




\section{Conclusions}

The assessment of literature sources has disclosed a complex structure of competence in ICT the major constituents of which are basic and educational ICT competencies. These components are integrated by the teachers' needs that may vary from knowledge of how to operate ICT to the abilities to apply them in educational practice.

The would-be teachers are good at ordinary abilities demonstrating basic ICT competence. They succeed in working with text, producing visual educational material, using electronic databases. However, they lack the extraordinary abilities demonstrating basic ICT competence, i.e., knowledge of how to design educational software and personal websites on the Internet need to be improved. Furthermore, within teaching practice, the students should more efficiently use the Internet for the purposes of searching for educational material and effective collaboration.

Teaching practice revealed educational ICT competence of would-be teachers including the ability to produce visual material using computer assistance and to design educational software. Nevertheless, teacher training must increase their abilities to work with enriched learning environments in the classroom and apply ICT employing active and traditional methods of teaching.

Research has confirmed that development of would-be teachers' competence in ICT is a permanent process that starts yet until the studies at university. The existing practice of teacher training nationwide shows that a three year period passes from the start of learning informatics in forms 11 and 12 at secondary school to the first professional activity - teaching practice. This period of time is important due to different factors that determine development of competence in ICT: formal and informal studies, learning motivation and experience, previously acquired skills, relationship with studying, self-help and other factors. The development of the respondents' competence in ICT was not separated from these factors, i.e., we researched a real phenomenon of ICT competence development rather than a simplified model isolated from the environment factors. Our study showed the impact of learning informatics in forms 11 and 12 on the development of basic ICT competence. It has been established that learning informatics in secondary school is important to the development of extraordinary abilities demonstrating basic ICT competence (visual static educational material, visual dynamic (animated) educational material, producing visual dynamic audio-equipped educational material using ICT, using the Internet for the purpose of searching for educational material). This conclusion reflects the objectives of teaching informatics in national secondary school (forms 11 and 12). The teaching goals focus on educating a person able to improve skills at information technological activity and on developing general abilities to work.

The relationship between the development of educational ICT competence and the format of learning informatics in forms 11 and 12 cannot be unambiguously reasoned. When teaching informatics in secondary school, the educational aspects of applying ICT are not considered. Therefore, a direct relationship is impossible. However, in some cases, it has been found out that successful ICT application in educational practice is determined by basic ICT competencies. Research proved that the students who learnt informatics in 
forms 11 and 12 at advanced level more successfully applied visual educational material produced using computer assistance, enriched ICT learning environments, traditional and active methods of teaching. Research data confirms the integrity of the structural components (basic and educational ICT competencies) of competence in ICT.

\section{References}

Anderson, J., T. Weert et al. (Eds.) (2002). Information and Communication Technology in Education. UNESCO, Paris.

Andresen, B.B., and K. Brink (2002). Multimedia in education: Specialised training course. In Specialised Training Course. UNESCO Institute For Information Technologies In Education, Moscow.

Ashworth, P., and J.J. Saxton (1991). On competence. Journal of Further and Higher Education, 2(14), 3-25.

Becker, H.J., and R.E. Anderson (1998). Teaching, Learning and Computing 1998: Teacher's Survey. http: / / www.crito.uci.edu/tlc/html/questionnaires.html

Becker, H.J., and J.L. Ravitz (2001). Computer Use by Teachers: Are Cuban's Predictions Correct? http: / / www.crito.uci.edu/tlc/findings/conferences-pdf/aera_2001.pdf

Coughlin, E. (1999). Professional Competencies for the Digital Age Classroom. http: / / www. iste.org/L\&L/archive/vol27/no3 / features / coughlin/index.html

Coughlin, E., and C. Lemke (1999). A continium for Profesional Development: Gauging Professional Competency fot Technology-Supported Learning. http: / / www.mff.org/pubs / Me159.pdf

Cuban, L. (2001). Oversold and Underused: Computers in the Classroom. Harvard University Press, Cambridge, MA. http: / / www . hup. harvard. edu/pdf / CUBOVE.pdf

Dagienè, V. (2004) Informacinių technologiju taikymo švietime konceptualusis pagrindimas (in Lithuanian, Conceptual Reasoning of Information Technologies Application in Education) http: / / www. leidykla.vu.1t/inetleid/inf-mok/25/str12.html

Dexter, S.L., R.E. Anderson and H.J. Becer (2000). Teachers'views of computers as catalysts for changes in their teaching pratice. Journal of Reasearch on Computing in Education, 3(31), 221-239.

Eunjoo, O., and F. Russell (2002). Preservice teachers“ perceptions of an introductory instructional technology course. Electronic Journal for the Integration of Technology in Education. http: / / ejite.isu.edu/Volume3No1/Oh.htm

Fuchs, T., and L. Woessmann (2004). Computers and Student Learning: Bivariate and Multivariate Evidence on the Availability and Use of Computers at Home and at School. http: / /www.res.org.uk/econometrics/504.pdf

Hattler, J.A. (1999). Technology for Preservice Teachers: “Driver Education” for the Information Superhighway.

http: //eric.ed.gov/ERICWebPortal/Home.portal?_nfpb=true\&_pageLabel =RecordDetails\&ERICExtSearch_SearchValue_0=EJ610113\&ERICExtSearch _SearchType_0=eric_accno\&objectId=0900000b800076f1

International Society for Technology in Education (2000). Educational Technology Standards and Performance Indicators for All Teachers. http: / / cnets. iste.org/teachers/t_stands.html

Jonassen, D., K. Peck and B. Wilson (1999). Learning With Technology: A Constructivist Perspective. Upper Saddle River, NJ Prentice Hall.

Jonassen, D.H. (1996). Computers in the Classroom: Mindtools for Critical Thinking. Prentice Hall Inc., New Jersey. http: / / www . coe.missouri.edu/ jonassen/Mindtools.pdf

Jonassen, D.H. (1999). Designing constructivist learning environments. In C.M. Reigeluth (Ed.), InstructionalDesign Theories and Models. A New Paradigm of Instructional Theory, vol. II, pp. 215-240.

Jucevičienè, P., and V. Brazdeikis (2003). Pedagogo IKT kompetencijos dinamiškos struktūros pagrindimas (in Lithuanian, Grounding the Dynamic Structure of Educator's ICT Competence). Socialiniai mokslai, 39(2), 70-81.

Knierzinger, A., S. Rosvik and E. Schmidt (Eds.) (2002). Elementary ICT Curriculum for Teacher Training. UNESCO Institute For Information Technologies In Education, Moscow. 
Li, S.C., S.C. Kong, F.L. Lee and J.Henri (2006). Capacity building for lifelong learning: a study of pratitioners' perceptions on information literacy framework. Informatics in Education, 5(2), 219-231.

Markauskaitė, L. (1999). Informaciniai gebejjimai humanitarinių ir tiksliujų mokslų sanglaudoje (in Lithuanian, Information skills as a liberal art and exact science, Information Sciencies). Informacijos mokslai, 10, 38-52.

Ozmon, H.A., and S.M. Craver (1996). Filosofiniai ugdymo pagrindai (in Lithuanian, The basics of philosophical education). Leidybos centras, Vilnius.

Papert, S. (1997). Why school reform is impossible. The Journal of the Learning Sciences, 6(4), 417-427.

Powers, R., and W. Blubaugh (2005). Technology in mathematics education: preparing teachers for the future. Contemporary Issues in Technology and Teacher Education, 5(3), 254-270.

http: / / www. editlib.org/index. cfm? fuseaction=Reader.ViewAbstract\&paper -id $=5474$

Rautopuro, J., S. Pontinen and J. Kukkonen (2006). Towards the information society - the case of finnnish teacher education. Informatics in Education, 5(2), 285-300.

Resta, P., A. Semenov et al. (Eds.) (2002). Information and Communication Technology in Education. UNESCO, Paris.

Schacter, J. (1999). The Impact of Education Technology on Student Achievement: what the most Current Research Has to Say. http : / / www . mff . org/pubs / ME161.pdf

Shapiro, J.J., and S. Hughes (1996). Information literacy as a liberal art. Educom Review, 31(2). http: / / www . educause.edu/pub/er/review/reviewArticles/31231.html

Stuhlmann, J.M., and H.G. Taylor (1999). Preparing Echnically Competent Student Teachers: a Three Year Study of Interventions and Experiences. http://www. editlib.org/index.cfm? fuseaction= Reader. ViewAbstract\&paper_id=8983

Švietimo ir mokslo ministerija (2001). Pedagogo kompiuterinio raštingumo standartas (in Lithuanian, The Standards of Using ICT by the Teachers). www. emokykla.1t/admin/file.php?id=30

Troter, A., and L. Ellison (2001). Undersatnding competence and competency. In B. Davies and L. Ellison (Eds.), School Leadership for the 21st Century. OutledgeFalmer, London, pp. 36-53.

Urbonaitè, D. (1999). Informacinès kultūros teorinis pagrindimas (in Lithuanian, Theoretical foundations of information culture). Informacijos mokslai, 10, 38-52.

Witfelt, C. (2000). Educational multimedia and teachers' needs for new competencies: a study of compulsory school teachers' needs for competence to use educational multimedia. Educational Media International, 37(4), 235-241(7).

Wong, E.M.L., and S.C. Li (2006). Is ICT a lever for educational change? A study of impact of ICT implementation on teaching and learning in Hong Kong. Informatics in Education, 5(2), 317-336.

P. Pečiuliauskienè is an associate professor in the Department of Education Science at Vilnius Pedagogical University. She lectures on teaching methodology and multimedia instructional development and implementation. Her research interests include improvement of natural science didactics, application of informational technologies in educational practice of natural science subjects as well as distance teaching of physics.

M. Barkauskaite is the head of the Department of Education Science at Vilnius Pedagogical University, a member of Vilnius Pedagogical University Senate, the Chair of the Council of the Faculty of Pedagogy and Psychology as well as the editor-in-chief of the scientific journal "Pedagogika". Her scientific interests include important issues related to teacher training and application of information technologies in educational practice. 


\title{
Būsimuju mokytojų IKT taikymo kompetencija: raiška ir formavimosi prielaidos
}

\author{
Palmira PEČIULIAUSKIENĖ, Marija BARKAUSKAITĖ
}

Edukacinių technologijų kaita keičia mokytojo vaidmeni, reikalauja nauju kompetencijų. Mokslinèje literatūroje IKT taikymo kompetencija aprašoma kaip dviejų struktūrinių komponentu IKT bazinès ir IKT edukacinès kompetencijos visuma. I šią sampratą atsižvelgta atliekant būsimujų mokytojų IKT taikymo kompetencijos tyrimą. Straipsnyje nagrinejjama būsimujų mokytoju IKT taikymo kompetencijos raiška atliekant pedagoginę praktiką, informatikos mokymosi XI-XII klasejje ịtaka šios kompetencijos formavimuisi. Tyrimas parodè, kad būsimieji mokytojai yra gerai ịvaldę paprastesnius IKT bazinès kompetencijos bei IKT edukacinès kompetencijos gebėjimus. Nustatyta, kad būsimuju mokytojų IKT kompetencijos formavimasis yra permanentinis procesas, prasidedantis dar iki pedagoginiu studiju universitete, mokantis informatikos XI-XII klasèje. 